Marek Olędzki

Uniwersytet Łódzki

(iD)

Damian Waszak

Kalisz
OBLICZA WOJNY

TOM 2 - ARMIA KONTRA NATURA

ŁóDŹ 2020 • ISBN 978-83-8220-057-7 • s. 31-62

http://dx.doi.org/10.18778/8220-057-7.03

\title{
TERMOPILE PO TRZYKROĆ
}

Streszczenie. Położone w Grecji Termopile stanowiły szczególny twór ukształtowany przez Naturę, który w dziejach wojen epoki antyku odegrał istotną i z niczym nieporównywalną rolę. Stanowiły one swoiste "ucho igielne” utrudniające wszelkiego rodzaju najeźdźcom przedostanie się do Grecji środkowej i południowej, tj. tam, gdzie znajdowały się jej najważniejsze pod względem politycznym i ekonomicznym centra. Przesądziło o tym ich ukształtowanie, w postaci wąskiego pasażu między stromymi górami Kallidromos a brzegiem morza, czy dokładniej Zatoki Malijskiej. Geomorfologiczne badania uczonych greckich wspomnianą sytuację jeszcze bardziej uszczegółowiły, udowodniając, że obok stromych gór znajdowało się rozległe bagnisko utworzone przez bijące powyżej ciepłe źródła siarkowe. Zatem wymienione bagno przesądziło o tym, że przejście przez Termopile było jeszcze węższe, w przybliżeniu około kilkudziesięciometrowe (ryc. 2). Rzeczone miejsce jest rezultatem rekonstrukcji, sytuacja obecna (ryc. 1), w niczym nie przypomina bowiem ukształtowania z czasów antycznych. Zasadniczą zmianę spowodowała działalność akumulacyjna pobliskiej rzeki Spercheios „odsuwając” brzeg zatoki o kilka kilometrów oraz przemiana dawnego bagniska w obecną tam dziś skałę trawertynu.

W swojej pracy autorzy analizują trzy wielkie konflikty zbrojne, jakie się w Termopilach rozegrały, które to z kolei określają trzy istotne daty roczne: 480, 279, 191 p.n.e. Przyjęte kryterium wyboru dotyczyło epoki, w której się wydarzyły, a więc antyku, a jednocześnie aktywnego tła, jakie stanowiła natura miejsca, która w omawianych czasach nie uległa wspomnianym wyżej zmianom. Poza tym wszystkie trzy opisywane konflikty, ściśle powiązane z sytuacją geomorfologiczną Termopil, charakteryzuje przebieg o daleko idących podobieństwach. W pierwszej odsłonie omówiono najazd wojsk Kserksesa na Grecję w 480 r. i bohaterstwo "Trzystu” pod dowództwem Leonidasa. Jak wiadomo casus ten znalazł już stosowne miejsce w literaturze przedmiotu. Oryginalnym wkładem niżej podpisanych jest natomiast uwzględnienie nowo odkrytych okoliczności geomorfologicznych dotyczących Termopil, o których wspomniano wyżej. W dużym stopniu dotyczy to także pozostałych dwóch omawianych w artykule konfliktów, na nowo przez autorów zinterpretowanych, tj. najazdu Brennosa i hord celtyckich zamierzających się osiedlić na terenie Hellady (rok 279) oraz niefortunnych zmagań Antiocha III z Rzymianami w roku 191.

Słowa kluczowe: Grecja, Termopile, badania geomorfologiczne, bagno, Kserkses, Persowie, Brennos, Celtowie, Etolowie, Rzymianie, Góry Kallidromos, Antioch III 


\section{Wstęp}

Zacząć wypada od truizmu, że Termopile, szczególny twór ukształtowany przez Naturę, odegrały w dziejach wielkich wojen epoki antyku rolę wybitną i niemal z niczym nieporównywalną, jak też były teatrem wydarzeń, które miały tendencję do wielokrotnego powtarzania się. Takich odsłon o charakterze wojennym, które rozegrały się tu tylko w starożytności było co najmniej pięć1. Batalia najsławniejsza, znana wszem i wobec, rozegrała się w roku $480^{2}$ i jest zawsze kojarzona z bohaterstwem „Trzystu” dowodzonych przez spartańskiego herosa Leonidasa ${ }^{3}$, casus drugi, w stopniu nie mniejszym oświetlony przez źródła, to najazd Celtów pod wodzą Brennosa na Helladę - rok 279, który w tym uchu igielnym, jakie stanowiły Termopile, miał również dramatyczny przebieg ${ }^{4}$. Nieco tylko mniejszy wydźwięk w źródłach wywołała kolejna batalia, która tam się toczyła, a której konsekwencje polityczne były jak wiadomo dużo dalej idące, mianowicie starcie sił Antiocha III Wielkiego z Rzymianami w $191 \mathrm{r}$. Co zaś się tyczy pozostałych dwóch zdarzeń, które rozegrały się w kontekście Termopil, to mają one trochę inny wymiar, nie tyle kwantytatywny, co kwalitatywny. Mowa tu o przejściu przez termopilski korytarz hord kostobockich w roku 171 n.e., mało znanych uczestników wojen markomańskich, których odparto dopiero na terenie Attyki ${ }^{5}$ oraz o analogicznych działaniach oddziałów gockich Alaryka w roku 396 n.e. Jeśli chodzi o tych pierwszych, to nic nam nie wiadomo jak wyglądało ich przejście przez Termopile, aczkolwiek na pewno przez nie przeszli, natomiast co do przedsięwzięć Alaryka sprawa jest bardziej czytelna. Ten wybitny wódz i polityk umiejętnie wykorzystujący animozje między zachodnią a wschodnią częścią Imperium, zaraz po systematycznym

${ }^{1}$ Przy czym nie mówimy tu o lokalnych potyczkach, np. między Fokijczykami i Tesalami.

2 Wszystkie daty, o ile nie zaznaczono inaczej, dotyczą okresu p.n.e.

${ }^{3}$ Ostatnie opracowania w jęz. pol., vide: N. Fields, Termopile 480 p.n.e. Ostatnia walka Trzystu, Kraków 2008; M. Woźniak, Termopile i Artemizjon 480 p.n.e. Pierwsza linia obrony Hellady, Zabrze-Tarnowskie Góry 2015 (non vidimus), a także proponowane przez nas ujęcie zawarte w niniejszej pracy.

${ }^{4}$ Ostatnio M. OlęDzki, A. Dubicki, Celtowie w natarciu. Termopile i Delfy w 279 roku przed Chr., [w:] Celtica. Studia z dziejów Celtów, t. 5, red. D. WAszaK, Kalisz-Warszawa 2018, s. 58-78. Problematykę dotyczącą Termopil w kontekście najazdu Brennosa prezentujemy rzecz jasna także poniżej, przy czym niektóre kwestie tam zawarte są obecnie przez nas na nowo zinterpretowane.

5 A. Dubicki, M. OlęDzki, Cosstoboci - less known participants of the Marcomannic wars, „Ephemeris Napocensis” 2018, t. 28, s. 156-166. 
złupieniu Tracji i Illyrikum, przeniósł działalność tego typu na terytorium Achai ${ }^{6}$. Jej ówczesnym namiestnikiem był Antiochus, a komendantem Termopil Geroncjusz, obaj dysponujący niewielkimi tylko siłami. Owa słabość oraz polityczne intrygi Konstantynopola spowodowały, że Alaryk przeszedł przez Termopile „bezboleśnie”, zajmując następnie południową Grecję i Peloponez. Choć należy tu dodać, że większych miast (np. Teb i Aten) nie udało mu się zdobyć7. Ostatecznie ustąpił z tych obszarów (rok 397 n.e.) obawiając się konfrontacji ze Stylichonem i wojskami zachodniorzymskimi, w rezultacie czego na jakiś czas wycofał się do Epiru ${ }^{8}$.

We wspomnianych dwóch przypadkach wyraźny jest brak determinacji u obrońców i wykazana słabość wynikająca z niedostatku sił zbrojnych zdolnych przeciwstawić się najazdowi. Na przykład, kiedy Kostobokowie grasowali po Helladzie większość wojsk rzymskich prowadziła ofensywę przeciwko Markomanom i Kwadom na północ od Dunaju, podczas gdy inna ich część broniła granic Dacji ${ }^{9}$. Natomiast kiedy przez Bałkany i Grecję przemieszczał się Alaryk ze swoimi ludźmi, wojska zachodniorzymskie koncentrowały się na obronie Italii, wschodniorzymskie zaś osłaniały Konstantynopol. Wszakże, jak sądzimy, pojawił się w obu przypadkach jeszcze jeden niebagatelny czynnik, który mógł też wpłynąć determinująco, mianowicie zmiany geomorfologiczne termopilskiego pasażu, który z upływem czasu (od najazdu Kserksesa do najazdu Alaryka upłynęło na przykład blisko 900 lat) tracił walor wąskiego przejścia, a więc swoje strategiczne znaczenie. Dlaczego (?), kwestia ta zostanie omówiona niżej.

W związku z tym, co zostało dotychczas powiedziane, wybraliśmy trzy zasygnalizowane wstępnie starcia bitewne, $\mathrm{z}$ roku: 480, 279 i $191^{10}$. Wszystkie trzy mają dobrą podbudowę źródłową, pozwalającą na przybliżoną rekonstrukcję wydarzeń. W pierwszym przypadku podstawą są Dzieje ojca historii Herodota ${ }^{11}$,

6 Problematyka ta, aczkolwiek zawsze marginalnie traktowana, znajduje liczny oddźwięk w opracowaniach. Ze starszych należy tu wymienić - K. ZAKRZEWsKI, U schytku świata antycznego, Warszawa 1964, s. 37-39, z nowszych zaś - M. KulıKowski, Wojny Rzymu z Gotami. Od III wieku do Alaryka, Oświęcim 2015, s. 132-133.

7 Zosimos, Nowa historia, Warszawa 1993, 5.3-4.

8 M. Kulikowski, op. cit., s. 132.

9 A. Dubicki, M. OlęDZKI, op.cit., passim.

10 Ponieważ od tego miejsca wszystkie podawane przez nas daty sytuują się przed naszą erą, określenie „p.n.e.” nie jest już dalej stosowane.

11 Herodot, Dzieje, tłum. S. Hammer, Warszawa 1954 [dalej: Hdt]. 
w drugim Pauzaniaszowa Wędrówka po Helladzie ${ }^{12}$ oraz skompilowany przez Justyna Zarys dziejów powszechnych starożytności na podstawie Pompejusza Trogusa ${ }^{13}$, natomiast w trzecim, stanowi je Historia Rzymska Appiana z Aleksandriii ${ }^{14}$. Poza tym wymienionych trzech batalii nie oddzielał od siebie szczególnie długi interwał czasowy. Każdy z omawianych przypadków zostanie przedstawiony według tego samego schematu zawierającego się w czterech następujących po sobie ujęciach. Ergo, podana zostanie w skrócie geneza konfliktu, duo, scharakteryzowane będą uzbrojenie i siły przeciwników, tertio, naświetlony przebieg wydarzeń zbrojnych, quarto, ich finał. Jednak najpierw postaramy się omówić pokrótce cechy geomorfologiczne samych Termopil, aktywnego tła wszystkich trzech wydarzeń militarnych.

\section{Termopile w aspekcie geomorfologicznym}

Przez ostatnie dwa tysiące lat z okładem krajobraz Termopil uległ daleko idącym przekształceniom (ryc. 1). Sprawiła to głównie akumulacyjna działalność rzeki Spercheios wpadającej do Zatoki Malijskiej kilka kilometrów na północny zachód od Termopil. Skumulowana ilość materiału mineralogicznego spowodowała ostatecznie, że obecna linia brzegowa morza, a dokładniej wymienionej zatoki, odsunęła się od termopilskiego przesmyku o około $4-6 \mathrm{~km}^{15}$. A zatem utraciły one walor wąskiego przejścia, które w dotychczasowych opracowaniach było zawsze jednoznacznie definiowane. Nic Fields pisał na przykład: „Gdy Leonidas stawał pod Termopilami, między górami po jego lewej ręce a morzem po prawej było jedynie wąskie przejście. Góry owe, łańcuch

12 Pauzaniasz, Wędrówka po Helladzie. U stóp boga Apollona, Wrocław 1989 [dalej: Paus.].

13 Marek Junianus Justynus, Zarys dziejów powszechnych starożytności na podstawie Pompejusza Trogusa, tłum. I. Lewandowski, Warszawa 1988. Przy czym autor ten poświęca jedynie nieco miejsca początkowi kampanii Brennosa, a następnie jego działaniom w Delfach, kwestię bitwy termopilskiej natomiast marginalizuje. Zatem PAUZANIASZ stanowi główne, wyczerpujące źródło na jej temat.

14 Appian z Aleksandrii, Historia Rzymska, t. 1-2, tłum. L. Piotrowicz, Wrocław 1957. Od tego miejsca będziemy korzystać ze skrótów źródłowych zawartych w Oxford Classical Dictionary, ed. S. Hornblower et al., $4^{\text {th }}$ ed., Oxford-New York 2012.

15 Podane tu różnice odległości o dużej amplitudzie wynikają z faktu, że wybrzeże jest nierówne i postrzępione. 


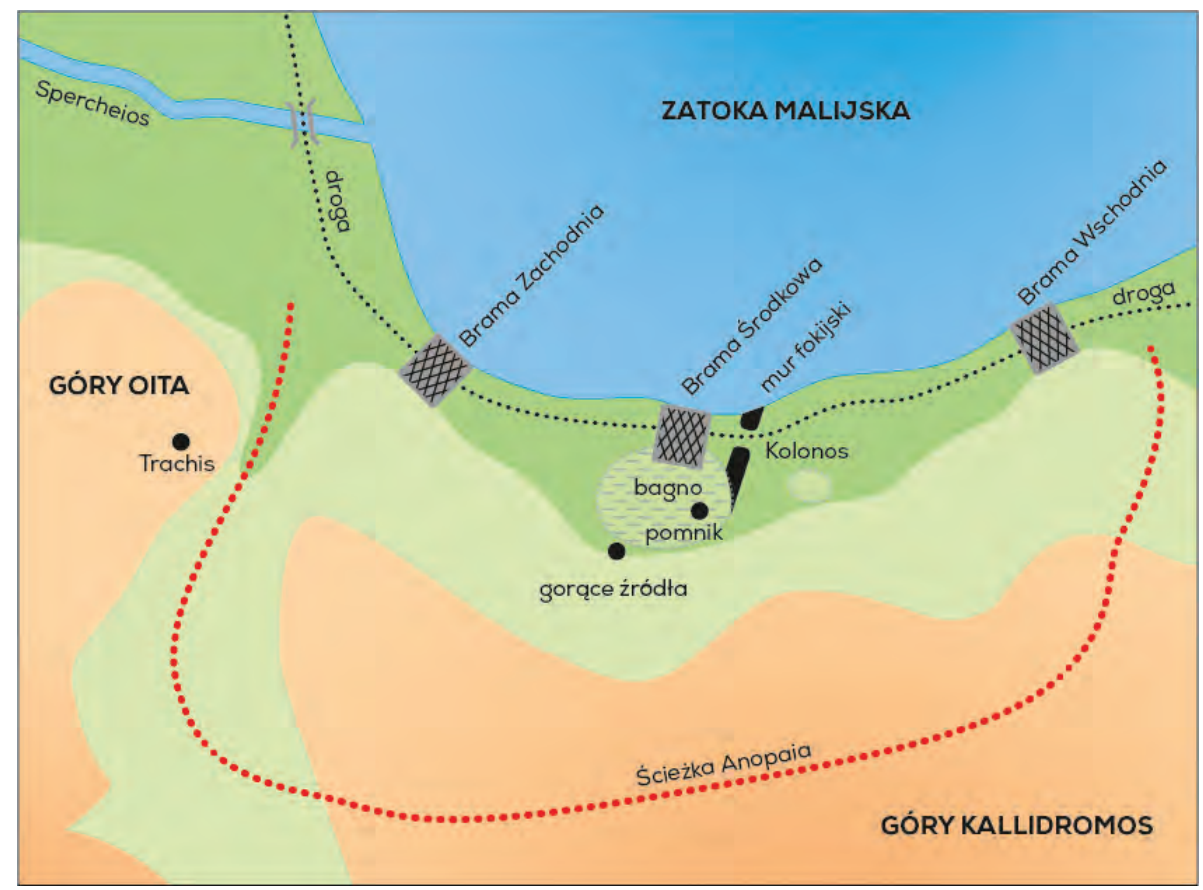

Ryc. 1. Przybliżona mapa geomorfologiczna Termopil (autorzy J. Apanowicz, M. OlęDzkı. D. WAszak)

Kallidromos, rozciągają się z zachodu na wschód wzdłuż wybrzeży Zatoki Malijskiej i w trzech miejscach podchodzą bardzo blisko morza. Dwa z tych miejsc były jeszcze węższe - jedno położone na wschodzie (Brama Wschodnia), drugie zaś na zachodzie (Brama Zachodnia) - od wybranej przez Spartanina pozycji (Brama Środkowa), która i tak miała szerokość ledwie 15 metrów. Jednakże Leonidas wykluczył je ze swojego planu, ponieważ w obydwu tych miejscach zbocza górskie, choć strome, nie były urwiste. Dlatego też wybrał nieco szerszy front, jednak taki, w którym jego słabsza lewa flanka była chroniona przez urwiste skały, górujące nad Bramą Środkową na jakieś $1000 \mathrm{~m}$. $\mathrm{Z}$ wybraną przez niego pozycją łączyła się też inna korzyść. Fokijczycy wiele lat wcześniej wznieśli przy środkowej bramie mur obronny, którego celem było zabezpieczenie ich przed arcywrogami z północy - Tesalczykami”16. Podobnie, aczkolwiek znacznie krócej, ujęli to samo Marek Olędzki i Andrzej Dubicki opisujący sytuację związaną z najazdem Celtów pod wodzą Brennosa. Ich bowiem

${ }^{16}$ N. Fields, op. cit., s. 62. 
zdaniem - „Termopile był to wąski pas lądu między urwiskiem a brzegiem morza, później miejsce to uległo całkowitemu przeobrażeniu” ${ }^{17}$. Jednocześnie cała trójka wymienionych autorów jest zgodna, że działania zbrojne rozgrywały się w najszerszej, tzw. Środkowej Bramie, z której prowadziło długie przejście do Wschodniej Bramy (mające około 1,5 km), dające możliwość etapowego wycofywania się oraz kontratakowania ${ }^{18} \mathrm{i}$ dodatkowo ufortyfikowane poprzecznym murem wzniesionym niegdyś przez Fokijczyków. Mur ten stanowił zatem wspomagający element obrony pod warunkiem, że wróg nie obszedł masywu gór Kallidromos od południa i nie zaatakował od wschodu, biorąc obrońców $\mathrm{w}$ tzw. kleszcze, co w dwóch z opisanych przez nas przypadków de facto nastąpiło (w latach 480 i 191). Dlatego też ostatecznym etapem obrony dla tych, którym nie udało się w porę wycofać, stawał się zazwyczaj pagórek Kolonos usytuowany nieopodal wspomnianego muru. Przy czym w każdym wypadku była to obrona straceńcza.

Dokładną lokalizację działań zbrojnych, a zarazem weryfikację dotychczasowych ustaleń, przyniosły jednak dopiero kompleksowe badania terenowe przeprowadzone przez uczonych greckich reprezentujących takie dyscypliny badawcze, jak geologia, stratygrafia i paleontologia, które w praktyce wsparto metodami technicznymi, w tym np. licznymi odwiertami. Ich rezultaty znalazły z kolei wyraz w opracowanej tomografii komputerowej zbadanego terenu i jego geologicznej analizie ${ }^{19}$. Wyniki te, w połączeniu z interpretacją źródeł antycznych, przede wszystkim Herodota i Appiana, pozwalają aktualnie na uszczegółowienie i sprecyzowanie rzeczywistych działań, jakie zaszły w Termopilach. Zacznijmy więc od przesłanek naturalnych, dostarczonych przez owe badania (ryc. 2). Jak ogólnie wiadomo nazwę przesmyku - Thermopylae, należy rozumieć jako gorące wrota czy też bramy, co potwierdza istnienie tak w starożytności, jak i dzisiaj gorących źródeł siarkowych wypływających z masywu gór Kallidromos, dokładnie tam, gdzie lokalizuje się tzw. Bramę Środkową. Spływające z dużej wysokości wody termalne były, z tego co wiadomo, tak wielotorowo pokierowane przez Fokijczyków, że utworzyły wespół ze środowiskiem glebowym i roślinno-zwierzęcym niezwykle rozległe bagnisko, o średnicy około 150-200 m. Obecnie

\footnotetext{
17 M. OlęDZKi, A. Dubicki, op. cit., s. 72.

18 Wszelkie manewry oskrzydlające były w tej sytuacji z oczywistych względów wykluczone.

$19 \mathrm{~K}$. Vouvalidis et al., Palaeogeographical reconstruction of the battle terrain in Ancient Thermopylae, Greece, „Geodinamica Acta” 2010, vol. 23, No 5-6, s. 241-253.
} 


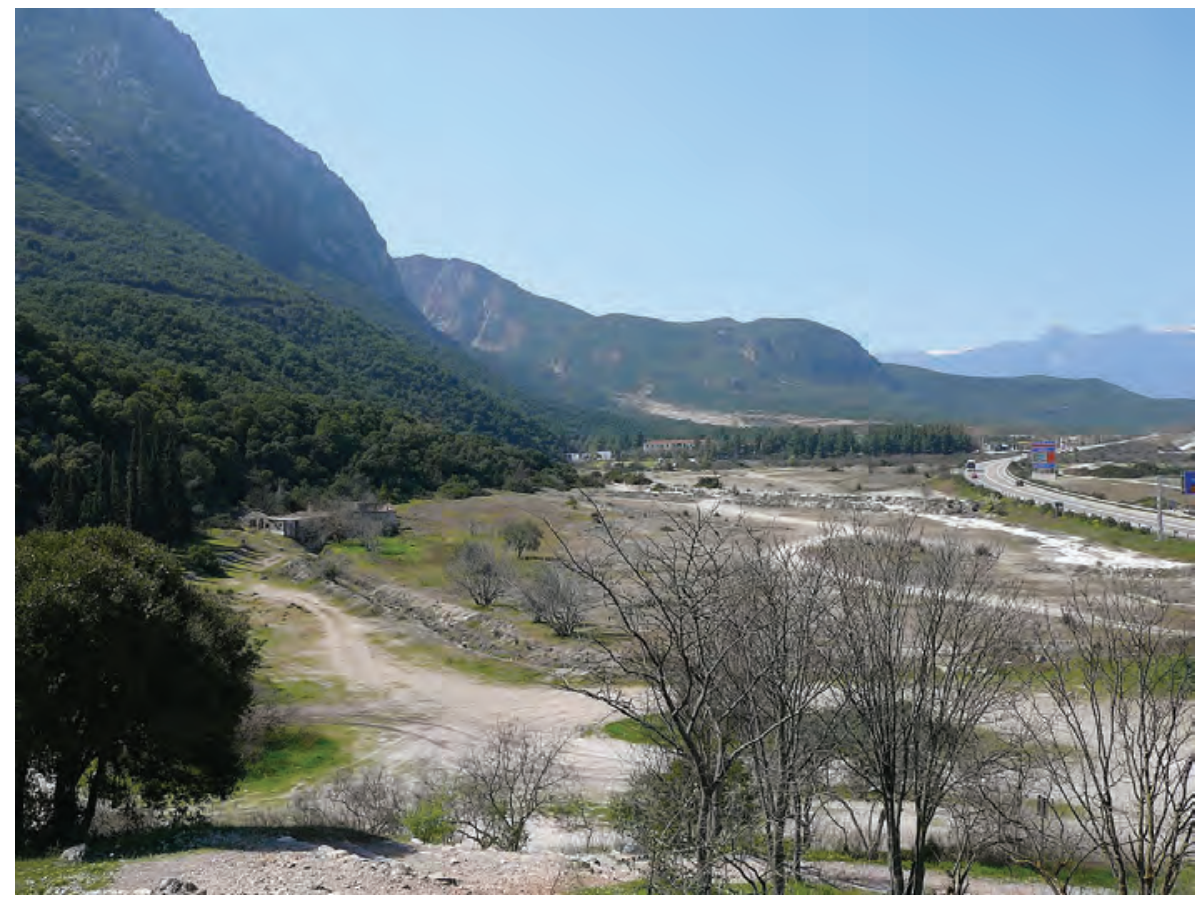

Ryc. 2. Brama Środkowa widziana ze wzgórza Kolonos, stan obecny (Źródło: Creative Commons)

bagnisko zachowało się w postaci szczątkowej, natomiast na jego miejsce, dzięki działalności wymienionych wód wytrącił się wapienny tuf w postaci tzw. trawertynu ${ }^{20}$. Obraz uzyskany przez obecne badania przyrodnicze harmonizuje zatem w zupełności ze słowami Herodota, który stwierdza, że: „Na zachód od Termopil znajduje się niedostępna i stroma góra, wysoka, ciągnąca się aż do gór Ojta; na wschód zaś droga ta łączy się bezpośrednio z morzem i bagnami [podkreślenie autorów]. A są w tym wąwozie ciepłe kąpiele, które krajowcy nazywają Chytroj, przy nich zaś wzniesiony jest ołtarz Heraklesa. W tymże wąwozie wybudowany jest mur i w dawnych czasach były w nim bramy. Wystawili go Fokijczycy z obawy przed Tesalami”21. W podobnych słowach ujmuje to Appian, który opisuje już trzecią, ostatnią z analizowanych przez nas termopilskich bitew. Jego bowiem zdaniem: „Termopile mianowicie stanowią wąskie, długie

${ }^{20}$ Akumulacja trawertynu po 2500 latach posiada dziś około 13 metrów miąższości, Ibidem, s. 252.

${ }^{21}$ HDT, 7.176. Opis ten powstał mniej więcej 50 lat po bitwie z Persami. 
przejście, osłonięte z jednej strony przez burzliwe, pozbawione portów morze, z drugiej strony przez niedostępne i przepaściste bagna [podkreślenie autorów]. Ponad nimi wznoszą się dwa strome szczyty górskie, z których jeden zwie się Teichius, a drugi Kallidromus. Znajdują się w tym miejscu źródła ciepłych wód, od których pochodzi właśnie nazwa Termopile"22. Sceneria ówczesnych trzech bitew wydaje się więc już teraz dość przejrzysta, nie wspomnieliśmy nic jedynie o wąskim miejscu między bagniskiem a morzem, tj. tam, gdzie wojownik każdej ze stron mógł pewnie postawić swoją stopę, jednym słowem o tym miejscu, gdzie za każdym razem dochodziło do inicjalnej konfrontacji. Według Hammonda i Fieldsa ten dystans wynosił jedynie $15 \mathrm{~m}^{23}$, natomiast badania, na których się opieramy sugerują, że był on znacznie szerszy, wynosząc najprawdopodobniej około 30-50 m (patrz wyżej). Zdaje się to też wspierać logika wydarzeń zgodna z dopuszczalnymi założeniami, a zwłaszcza taktycznymi możliwościami realizacyjnymi, jakie pozostawały w gestii wojujących tutaj stron.

\section{Termopile 480 r. p.n.e.}

\section{Przyczyny}

Po śmierci Dariusza władzę w państwie perskim objął jego syn Kserkses (486 rok). Syn „odziedziczył” po ojcu kwestię rozliczenia się z Grekami za wydarzenia z roku 490, kiedy to Ateńczycy pokonali pod Maratonem wyprawę perską dowodzoną przez Mardoniusza ${ }^{24}$. Jednak przygotowania do wyprawy znacznie się odwlekły, m.in. z powodu buntu w Egipcie, który Persowie tłumili w latach 487-485 25 . Oznaką zbliżającej się wojny było poselstwo perskie, które w $481 \mathrm{r}$. wyruszyło do państw greckich z żądaniem „ognia i wody”26. Część polis greckich

22 Appian z AleksandriI, Historia Rzymska, t. 1-2, Wrocław 1957 [dalej: App., Syr.], 76-77.

23 N. Fields, op. cit., s. 62; N.G.L. Hammond, Dzieje Grecji, Warszawa 1994, s. 288.

${ }^{24}$ Szczególnym stymulatorem był jednak fakt, że przedtem Ateńczycy, a także Spartanie, zamordowali posłów perskich. O wyprawie Mardoniusza i bitwie pod Maratonem: N.G.L. Hammond, op. cit., s. 266-270; R. Kulesza, Maraton, Warszawa 2005, s. 71-80, 109-121 (w tymże opracowaniu podstawowa literatura).

25 Diodorus of Sicily, The Library of the History, vol. 2: Books 2.35-4.58, London-Cambridge 1967 [dalej: Diod. Sic.] 11.2.3-4; HDT, 7.1-37.

26 Diod. Sic., 11.3.5; НDT, 7.131. 
(wśród nich znalazły się m.in. niektóre z polis Beotów oraz Tessalowie) od razu przyjęła zwierzchnictwo Persów. Wymowne było to, że posłowie nie zawitali ani do Aten, ani do Sparty, dwóch miast-państw, które w pamiętnym roku 490, jako jedne z nielicznych, zdecydowały się stawić stanowczy opór imperium perskiemu. Był to widomy znak, że Kserkses nie chciał negocjować z tymi państwami, zamierzając je przykładnie ukarać, jak też w ogólności zająć obszar Hellady ${ }^{27}$.

Grecy, którzy do momentu przybycia owego poselstwa lekceważyli sobie zagrożenie perskie, teraz podjęli środki zaradcze. Te miasta-państwa, które zdecydowały się nie poddać, wysłały swoich przedstawicieli do Sparty. Tam też został zaprzysiężony Związek Helleński, złożony z 31 państw członkowskich. Kongres Związku zbierał się na Istmie Korynckim, a decyzje podejmowano w nim większością głosów ${ }^{28}$. Wkrótce po utworzeniu Związek wysłał poselstwa do polis greckich znajdujących się w basenie Morza Śródziemnego (m.in. na Kretę i do Syrakuz na Sycylii), aby uzyskać tam wsparcie. W większości przypadków prośby i zachęty spotkały się z odmową, przy czym znaczną rolę odegrali tu „medyzujący”, tj. okazujący poparcie dla sprawy perskiej kapłani wyroczni w Delfach. Przepowiednie Pytii zniechęcały bowiem zarówno potencjalnych sojuszników, jak i głównych członków związku, tj. Ateny i Spartę, do stawiania oporu przeważającym siłom perskim ${ }^{29}$. Dopiero ostatnia wizja Pytii wlała nieco otuchy w serca Ateńczyków ${ }^{30}$.

Wiosną 480 r. wojska Wielkiego Króla opuściły Sardes, główny punkt zborny oddziałów przeznaczonych do inwazji na Grecję. Armia perska liczyła prawdopodobnie około 100-200 000 ludzi, których wspierało 1207 okrętów ${ }^{31}$.

${ }^{27} \mathrm{HDT}, 7.132-133$.

${ }^{28}$ O Związku Helleńskim: Diod. Sic., 11.3.3-4; HDT, 7.145-146; N.G.L. HAMmOND, op. cit., s. 280-281; G. LACH, Salamina-Plateje 480-479 p.n.e., Warszawa 2010, s. 123-124.

29 HDT., 7.148-172, 220.

${ }^{30}$ HDT., 7.141.

${ }^{31}$ Liczebność armii i floty perskiej jest różnie oceniana zarówno przez starożytnych, którzy szacowali je, zapewne ze względu na towarzyszące im tłumy niewojskowych, na przekraczające $1 \mathrm{mln}$ ludzi: Diod. Sic., 11.3.7-9, 5.2-3; НDT, 7.60, 80, 184-186, jak i współczesnych, dla przykładu: N.G.L. Hammond, op. cit., s. 283-284 (prawdopodobnie do 500000 i około 3000 okrętów); T. Łoposzko, Starożytne bitwy morskie, Gdańsk 1994, s. 69-71; B. SkŁadanek, Historia Persji, t. 1: Od czasów najdawniejszych do najazdu Arabów, Warszawa 1999, s. 125. Wykaz innych szacunków liczebności wojsk Kserksesa zebrał: F.E. RAY jr, Land Battles in $5^{\text {th }}$ Greece: A History and Analysis of 173 Engagements, Jefferson-London 2009, s. 69. 
Dla przeprawienia tych oddziałów Persowie zbudowali w Hellesponcie dwa mosty pontonowe złożone z okrętów. Kiedy wojska lądowe przeprawiły się przez nie, pomaszerowały wzdłuż wybrzeża będąc cały czas wspomagane i zaopatrywane przez towarzyszącą im flotę.

Greccy „związkowi” na prośbę Tessalów, których część zdecydowała się jednak stawić opór, wysłali korpus ekspedycyjny liczący 10000 hoplitów ${ }^{32}$. Ten, przy wsparciu Tessalów, miał bronić przejścia przez dolinę Tempe. Jednakże w wyniku niepewnej postawy tesalskich polis oraz wobec ostrzeżenia wystosowanego przez króla macedońskiego Aleksandra, wspomniane siły wycofały się $^{33}$. Tymczasem Kongres Związku, który zebrał się na Istmie, ustalił, że obrona zostanie podjęta zarówno na lądzie, jak i na morzu. W związku z tym siły lądowe miały zająć się obroną Termopil, tj. głównej bramy prowadzącej do środkowej Grecji. Do tego zadania wyznaczono około 6000-7000 hoplitów (w tym: 300 Spartan, 2800 Peloponezyjczyków, 700 Tespijczyków, 400 Tebańczyków, 1000 Fokijczyków oraz 1000 Lokrów Opunckich), którymi dowodził król Sparty Leonidas $^{34}$. Z kolei flota dowodzona przez Spartanina Eurybiadesa (przy znacznym wsparciu dowódcy ateńskiego Temistoklesa) zajęła pozycję w pobliżu przylądka Artemizjon. Jej zadaniem było powstrzymanie potężnej flotylli perskiej ${ }^{35}$.

\section{Przeciwnicy}

Do walki w Termopilach stanęly nie tylko różne podmioty polityczne świata greckiego, ale również zróżnicowane pod względem organizacji i uzbrojenia jednostki wojskowe. Zasadniczy trzon tych sił stanowiła ciężkozbrojna piechota - hoplici, w skład której wchodzili wszyscy wolni obywatele zobowiązani do służby wojskowej, których było stać na zakup odpowiedniego wyposażenia. Składało się ono z hełmu, najczęściej typu korynckiego, brązowego

32 Diod. Sic., 11.2.5; HDT, 7.173.

${ }_{33} \mathrm{HDT}, 7.173$.

${ }^{34}$ Podobnie, jak w przypadku armii perskiej, wygląda sprawa z określeniem stanu sił greckich: Diod. Sic., 11.4.5-7; HdT, 7.202-203, 228; N. Fields, op. cit., 51-52, 56; N.G.L. Hammond, op. cit., s. 286 (6-7000 hoplitów); G. LACH, op. cit., s. 143-144; F.E. RAY jr, op.cit., s. 71; B. SKŁADANEK, op. cit., s. 126 (4200); J. WARRY, Armie świata antycznego, Warszawa 1995, s. 29; R. KulEsza, Sparta w V-IV wieku p.n.e., Warszawa 2003, s. 189.

35 O flocie greckiej i bitwie pod Artemizjonem: N.G.L. Hammond, op. cit., s. 286-288, 290-292; G. LACH, op. cit., s. 141-143, 145-148, 150-151; T. ŁoposzKo, op. cit., s. 79-94; J. WARrY, op. cit., s. 28. 
bądź lnianego pancerza, miecza - kopis, tarczy - aspis i włóczni - doru oraz brązowych nagolennikiów ${ }^{36}$. Mniej zamożni służyli jako lekkozbrojni oszczepnicy i procarze. Formacje te uzupełniali poza tym nieliczni u Greków łucznicy i konni ${ }^{37}$. Hoplici walczyli w szyku zwartym zwanym falangą, o głębokości od kilku do kilkunastu szeregów, w którym każdy towarzysz stojący obok osłaniał tarczą swojego towarzysza ${ }^{38}$.

Siły perskie składały się natomiast z armii „stałej” złożonej z gwardii królewskiej, w której m.in. znajdowała się formacja tzw. nieśmiertelnych, licząca 10000 piechurów, a także z jazdy ${ }^{39}$. Oddziały te były uzupełnione przez kontyngenty państw i ludów sprzymierzonych bądź zależnych, wśród których znajdowali się m.in. Egipcjanie i Scytowie ${ }^{40}$. W zestawieniu z Grekami były to głównie formacje lekkie, uzbrojone w łuki, a także krótkie miecze typu akinakes. Broń defensywną stanowiły ponadto wiklinowe tarcze ${ }^{41}$. Perska taktyka polegała natomiast na obrzuceniu przeciwnika pociskami, a po jego dezorganizacji, na masowym uderzeniu piechoty wspartej na skrzydłach przez jazdę i rydwany ${ }^{42}$.

\section{Przebieg}

Siły greckie zdecydowały się stawić opór armii perskiej w tzw. Bramie Środkowej (ryc. 2). Dodatkową obronę stanowił w niej mur Fokijczyków wzniesiony około 575 r., w celu obrony przed Tessalami ${ }^{43}$. Jego linia biegła od strony

36 O uzbrojeniu hoplitów: N. Sekunda, The Greek Hoplite, 480-323 B.C., Oxford 2000, s. 9-17; B. SzubelaK, Hoplita grecki VII-V w. p.n.e. Studium bronioznawcze, Zabrze 2007; P. Connolly, Greece and Rome at War, London 2006, s. 51-63; F.E. RAY jr, op. cit., s. 9-10; J. WARRY, op. cit., s. 34-35, 37.

${ }^{37}$ P. Connolly, op. cit., s. 40-41; F.E. RaY jr, op.cit., s. 14-20.

38 O falandze: P. Connolly, op. cit., s. 37-48; F.E. RaY jr, op. cit., s. 10-14; J. WarRY, op. cit., s. 37, 39. Przebieg starcia między hoplitami: N. Sekunda, The Greek Hoplite..., s. 21-30.

${ }^{39}$ J. WARry, op. cit., s. 38; N. Sekunda, The Persian Army, 560-330 B.C., London 1992, s. 6-7; M.A. Woźniak, Armie starożytnej Persji. Od powstania państwa Achemenidów do upadku imperium sasanidzkiego, Zabrze 2010, s. 64-70.

${ }^{40}$ M.A. Woźniak, Armie..., s. 86-90. Wykaz ludów, które ponoć wyruszyły do Grecji zebrał: HDT, 7.61-86.

${ }^{41}$ O uzbrojeniu wojsk perskich: J. Warry, op. cit., s. 38-39; M.A. WoźniaK, Armie..., s. 39-57, $76-86$.

42 Taktyka armii perskiej, N. Sekunda, The Persian Army..., s. 15-16; M.A. Woźniak, Armie..., s. $57-63,90-94$.

${ }_{43} \mathrm{HDT}, 7.176$. 
zachodniej, tj. od skał wąwozu i bagien do znajdującego się na wschodzie wybrzeża morskiego. Dlatego też Grecy rozpoczęli działania od rekonstrukcji i wzmocnienia tej przeszkody. Ponieważ jednak udało się kiedyś Tessalom obejście muru ścieżką pasterską biegnącą wokół Termopil, dlatego też Leonidas wyznaczył kontyngent Fokijczyków do jej obsadzenia ${ }^{44}$.

Kiedy Persowie dotarli do Termopil ulokowali swój obóz w Bramie Zachodniej. Kserkses nie rozpoczął walki od razu, ale zwlekał przez cztery dni licząc na to, że wielkość jego armii zatrwoży i zdemoralizuje Greków. Następnie wysłał posłów z propozycją kapitulacji, tj. żądaniem „ziemi i wody”. Nie jest znana treść odpowiedzi, jakiej udzielił Leonidas na to zapytanie, źródła przekazały kilka jej wersji, ale na pewno odmówił ${ }^{45}$. Wkrótce potem nastąpił atak piechoty perskiej na pozycje greckie ulokowane przed murem. Pierwszy atak został krwawo odparty. Lekkozbrojni Persowie nie mogli bowiem przebić się przez linię falangi. Ponadto Grecy przy kolejnych atakach perskich stosowali taktykę pozorowanego odwrotu. Kiedy Persowie atakowali, hoplici cofali się ku murowi, za nimi zaś podążali perscy piechurzy. Grecy dokonywali wówczas błyskawicznego zwrotu i uderzali na zaskoczonych Persów. Jednocześnie ci ostatni nie mogli wykorzystać swoich łuczników, ponieważ ich wojska wciąż działały w zwarciu. Rezultatem były ogromne straty w ludziach po stronie perskiej ${ }^{46}$. Pod koniec dnia Kserkses rzucił do walki swoich „nieśmiertelnych”, ale i ci zostali odparci. Starcia następnego dnia miały podobny przebieg. Wtedy też do króla perskiego przybył pasterz Efialtes z Trachis, który wyraził chęć wskazania Persom obejścia pozycji greckich przez góry ${ }^{47}$. Kiedy nastała noc król perski wysłał „nieśmiertelnych” pod wodzą Hydarnesa, którzy - kierowani przez Efialtesa - ruszyli wskazaną przez niego trasą. W godzinach rannych kolumna perska spotkała się z Fokijczykami i po krótkiej walce zmusiła ich do wycofania się na pobliskie wzgórze. Persowie ich już jednak nie atakowali, natomiast pomaszerowali w pośpiechu dalej. Kiedy skupieni w Termopilach Grecy zorientowali się, było już za późno. W związku z takim obrotem spraw Leonidas odesłał większość swoich

44 HDT, 7.218.

45 Diod. Sic., 11.5.4-5 („dłuższa”, ale będąca zapewne wytworem samego Diodora); Plut., Moral., 225C („krótsza” brzmiąca Molon labe, tj. „przyjdź i weź sam”, jest bardziej prawdopodobna).

${ }^{46}$ HDT, 7.211.

${ }^{47}$ Diod. Sic., 11.8 .5 (nie podał imienia zdrajcy); HDT, 7.213. 
sił, pozostawiając przy swym boku jedynie Tebańczyków i Tespijczyków, którzy zdecydowali się zostać i stawić opór. Przy czym ci pierwsi sprzyjali Persom i podczas dalszego przebiegu bitwy nie zachowywali się aktywnie.

Trzeciego dnia Grecy stanęli jak poprzednio, gotowi do walki. Jednocześnie dla pełniejszego rozwinięcia szyku ustawili się nieco dalej od muru. Na tej pozycji dłuższy czas odpierali ataki perskie. Jednakże po tym, jak większość z nich połamała swoje włócznie, a także po tym jak w ferworze walki zginął sam Leonidas, niedobitki obrońców wycofały się za mur i skupiły na niewielkim pagórku zwanym Kolonos. W tym czasie kolumna „nieśmiertelnych”, prowadzona przez zdrajcę Efialtesa, zeszła ze ścieżki i wkroczyła do wąwozu. Wówczas Grecy zostali całkowicie otoczeni. Był to też ten moment, kiedy Tebańczycy poddali się Persom ${ }^{48}$. Pozostali greccy obrońcy wzgórza zostali zasypani gradem strzał, oszczepów i kamieni, które dokonały dzieła zniszczenia.

\section{Po bitwie}

Po zwycięstwie Kserkses rozkazał odnaleźć ciało Leonidasa, które kazał zdekapitować, a następnie wbić jego głowę na pal umieszczony w centrum pola bitwy ${ }^{49}$. Przy okazji wódz perski rozkazał skrzętnie zebrać większość ciał własnych wojowników, żeby ukryć poniesione straty. Następnie pomaszerował do opustoszałych Aten, które zajął przy minimalnym oporze i następnie zniszczył. Ostatecznie zaś miał jednak zostać pokonany i wycofać się z Grecji, sprawiły to dwa wielkie greckie zwycięstwa: Salamina (480 rok) i Plateje (479 rok), co nie jest już jednak przedmiotem naszej analizy. Po wojnie dzielni obrońcy Termopil zostali upamiętnieni stosownymi kolumnami i inskrypcjami. Wśród tych ostatnich znalazła się najsłynniejsza, ze znamiennym tekstem: „Gościu, oznajmij Lacedemończykom, że w boju poległszy - Tu spoczywamy po wiek, wiernie słuchając ich praw" ${ }^{50}$.

\footnotetext{
48 HDT, 7.233.

49 HDT, 7.238.

50 HDt, 7.228 (tłum. S. HAMmer).
} 


\section{Termopile 279 r. p.n.e.}

\section{Przyczyny}

O ekspansji Celtów na terenach środkowoeuropejskich czy też na Bałkanach informują nas w równym stopniu przekazy źródłowe, co dane archeologiczne. W wypadku tych drugich o ich tam fizycznej obecności świadczy występowanie tak zwanej kultury La Tène, rzecz oczywista w zwartej i dominującej postaci. Natomiast jej bardziej rozproszone ślady poczytywać można jedynie za kulturowy nurt latynizacji obejmujący autochtoniczne jednostki kulturowo-etniczne (Daków, Traków, Illirów itd.). Swoistą oś komunikacyjną dla przybywających z zachodu i północnego zachodu Celtów stanowił z pewnością Dunaj, wzdłuż którego docierali następnie do Kotliny Karpackiej i Siedmiogrodu ${ }^{51}$. Z kolei z rejonu ujść Drawy i Sawy do wymienionej wielkiej rzeki ekspandowali w kierunku Macedonii i Grecji. Pierwszym sygnałem świadczącym o ich nieodległej obecności był kontakt poselstwa celtyckiego z Aleksandrem Macedońskim prowadzącym wówczas kampanię przeciwko Triballom i Getom (335) ${ }^{52}$. W ćwierć wieku później relacje przybrały już stricte militarny charakter. Duża grupa Celtów podjęła wtedy próbę wdarcia się do Macedonii. Zatrzymał ją władca tego kraju Kassander, który zadał klęskę najeźdźcom w górach Hajmos. W roku 280 nastąpił jeszcze większy i bardziej dalekosiężny najazd. Tym razem wojska celtyckie podzielone były na trzy korpusy ${ }^{53}$. Pierwszy, pod dowództwem Brennosa i Akichoriosa, zaatakował graniczącą z Macedonią Pajonię, drugi, dowodzony przez Keretriosa, najechał na Trację, podczas gdy trzeci, którym kierował Bolgios, uderzył bezpośrednio na Macedonię. Temu ostatniemu próbował się przeciwstawić Ptolemeusz Keraunos z wojskami macedońskimi, ale w trakcie

${ }^{51}$ M. OlĘDZKI, Z problematyki latynizacji i celtyzacji na obszarze Kotliny Karpackiej, [w:] Archeologia et Historia. Ksiega jubileuszowa dedykowana Pani Profesor Romanie Barnycz-Gupieńcowej, red. L. Kajzer, Łódź 2000, s. 323-329 (tam cytowana literatura obcojęzyczna). Bardziej ogólnie vide: B. Cunliffe, Starożytni Celtowie, Warszawa 2003, s. 99-100.

52 Flawiusz Arrian, Wyprawa Aleksandra Wielkiego, Wrocław 2004 [dalej: Arr., Anab.] 1.4.4. W źródle mowa o tych Celtach, którzy znajdowali się już na Bałkanach, podczas gdy jeszcze wcześniej wojownicy celtyccy dali się poznać Grekom w działaniach na Peloponezie, w roku 369, jako najemnicy przysłani przez Dionizjosa tyrana Syrakuz celem wsparcia Spartan przeciwko wojskom Epaminondasa (Diod. Sic., 15.70.1).

${ }^{53}$ Paus., 10.19.5-6. 
bitwy został pochwycony i zgładzony, a jego wojska doznały sromotnej klę$\mathrm{ski}^{54}$. W rezultacie wszystkie trzy korpusy odniosły zwycięstwa i dokonawszy licznych zniszczeń i rabunków wycofały się na północ. Ich udana kampania, o wybitnie rabunkowym i rekonesansowym charakterze, stanowiła asumpt do planowanych dalszych działań, których całkiem realnym celem stawał się zabór położonych na południu terytoriów i trwałe na nich osadnictwo. Na wodza nowego przedsięwzięcia powołano wówczas Brennosa, fortunnego zwycięzcę z poprzedniego roku.

Gdybyśmy zatem chcieli pokrótce określić genezę najazdu Celtów na Helladę w roku 279, to należałoby kwestię tę ująć dynamicznie. Wydaje się nam bowiem, że z początku za cel Celtowie stawiali sobie jedynie rabunek cudzego mienia i pozyskiwanie niewolników, z naciskiem na „fachowców”, których można się było w Grecji spodziewać, natomiast po kampaniach zwieńczonych pełnym sukcesem ich apetyt wzrósł i głównym celem stało się powiększenie własnej „przestrzeni życiowej”, czyli osiedlenie się na obszarze, który można by było permanentnie eksploatować.

Początek wydarzeń przedstawiał się następująco. Kiedy idący z północy najeźdźcy wtargnęli do Macedonii wyszedł im naprzeciw strateg Sosthenes głównodowodzący armią macedońską, który wsławił się sukcesami z roku poprzedniego, kiedy udało mu się wyprzeć resztki Celtów poza granice państwa ${ }^{55}$. Tym razem jednak został w polu pokonany, a Macedonia po raz drugi doświadczyła skutków wojny i okupacji, aczkolwiek większych miast Celtom nie udało się zdobyćs ${ }^{56}$. Gdy już nie było czego rabować Celtowie ruszyli na południe, wzdłuż Zatoki Termajskiej i dotarli do Doliny Tempe, którą to rzeka Pinios uchodzi do wymienionej zatoki. Rozległa, przecinająca góry dolina stanowiła jednocześnie dogodną drogę wiodącą do serca Tessalii, jednego z największych i najsilniejszych państw Hellady i dodajmy, słynącego ze świetnej jazdy. Niemniej wkrótce najeźdźcy podporządkowali sobie całkowicie jej mieszkańców $^{57}$, których wojska zasiliły armię Brennosa i odgrywającego rolę jego alter ego Akichoriosa. Jest ponadto niemal pewne, że w Tessalii Brennos pozostawił tę część swoich ludzi, którzy nie posiadali bojowego znaczenia, a więc rodziny

\footnotetext{
${ }^{44}$ M. OlęDZKI, A. DubICKI, op.cit., s. 59.

55 Just., Epit., 24.5.

56 Ibidem, 24.6.

${ }^{57}$ Ibidem, 24.7.
} 
wojowników, markietanów itd., a także wydzielone kontyngenty mające strzec i ochraniać szlaki komunikacyjne prowadzące na północ. Następny etap działań stanowiła niewielka kraina Achaia Phtiotis, po sforsowaniu której Celtowie stanęli nad rzeką Spercheios, skąd do Termopil było już tylko kilka kroków.

\section{Przeciwnicy}

Doszliśmy więc do momentu, w którym należy określić, jak prezentowali się przeciwnicy, tj. Celtowie i Grecy, czyli jaki był ich potencjał wojskowy, rodzaj uzbrojenia oraz sposoby walki. Zacznijmy w takim razie od najeźdźców. Zdaniem autorów antycznych Celtowie dysponowali gigantyczną armią. Na przykład Diodor podaje liczbę 160000 wojowników ${ }^{58}$, Pauzaniasz aż $172400^{59}$, a nieco lepiej znający realia wojskowe Justyn - 40000 piechoty i 15000 jazdy $^{60}$. Oczywiście wszystkie podane tu cyfry są przesadzone, chyba że odniesiemy je do ogólnej masy przybyszy, która - jak skądinąd wiadomo - była tworem wieloplemiennym, poza wojownikami zawierającym także i inne elementy składowe, w postaci np. wspomnianych już rodzin wojowników, a więc kobiet, dzieci i starców, poza tym niewolników, jeńców itd., a wszystkich razem przewidywanych - jak nam się zdaje - do ewentualnej kolonizacji. Samych zaś wojowników nie mogło być z pewnością więcej niż 30 tysięcy ${ }^{61}$. Stanowili natomiast armię dobrze uzbrojoną i wyposażoną, posiadającą swoiste, wypracowane na własnym gruncie formy organizacji bojowej. O uzbrojeniu Celtów mówią nam źródła archeologiczne oraz przekazy autorów antycznych. W przypadku tych pierwszych brana jest głównie pod uwagę bogata i „standardowa” zawartość pochówków wojowników licznie występujących na obszarze kultury La Tène, przy czym interesujące są w tym wypadku tylko te groby - w przewadze inhumowane - które pochodzą z okresu, kiedy Celtowie parli na południe, tj. na obszary Grecji, Tracji i Anatolii (faza LT B2b datowana na lata 280-240). Odkrywane w tak datowanych grobach elementy uzbrojenia powielają pewien powtarzający się model złożony z długiego miecza, którego

58 Diod. SiC., 22.9.1.

59 PAUS. 10.19.9.

${ }^{60}$ Marek Junianus Justyn, Zarys dziejów powszechnych starożytności na podstawie Pompejusza Trogusa, Warszawa 1988 [dalej: Just., Epit.], 24.6.

${ }_{61}^{6}$ M. OlęDZKI, A. Dubicki, op. cit., s. 72. 

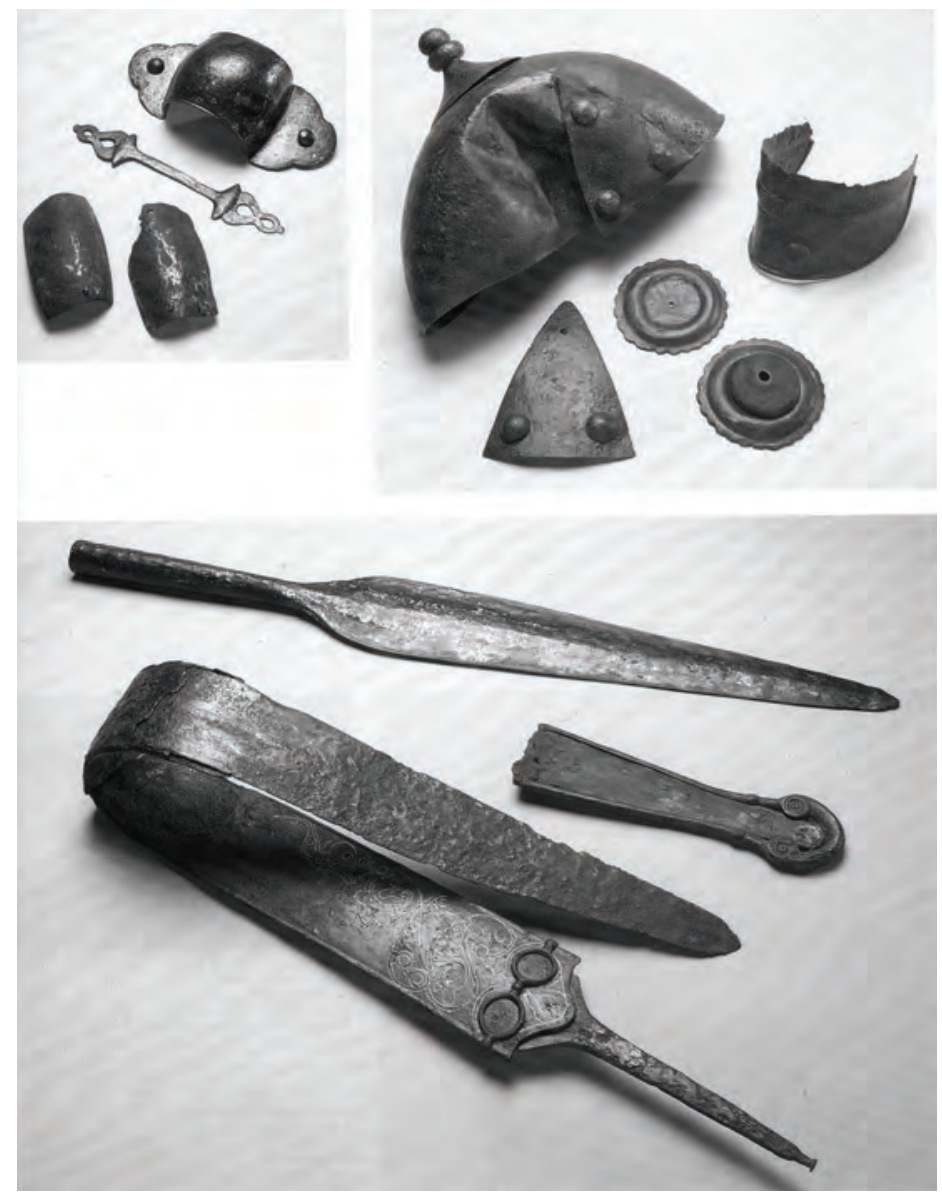

Ryc. 3. Wyposażenie grobu wojownika celtyckiego odkrytego w miejscowości Batina (Chorwacja), dawny obszar Skordysków (Źródło: M. Szabó, The Celts and their Movements in the Third Century B.C., [w:] The Celts, ed. S. Moscatı et al., Milan 1991)

pochwa ozdabiana była zazwyczaj bogatym ornamentem wytłaczanym, masywnego grotu włóczni oraz metalowych fragmentów tarczy, tj. wypukłego umba, a od wewnętrznej strony „rączki” zwanej imaczem ${ }^{62}$. Hełmy występowały sporadycznie i posiadały zazwyczaj zróżnicowaną formę $e^{63}$. Dobrą egzemplifikację takiego zestawu elementów uzbrojenia prezentuje grób z miejscowości Batina

${ }^{62}$ Element tego rodzaju po raz pierwszy opisał: HDT, 1.171.

${ }^{63}$ U. Schaff, Keltische Helme, [w:] Antike Helme. Sammlung Lipperheide und andere Bestände des Antikenmuseums Berlin, Mainz 1988, s. 293-317. 


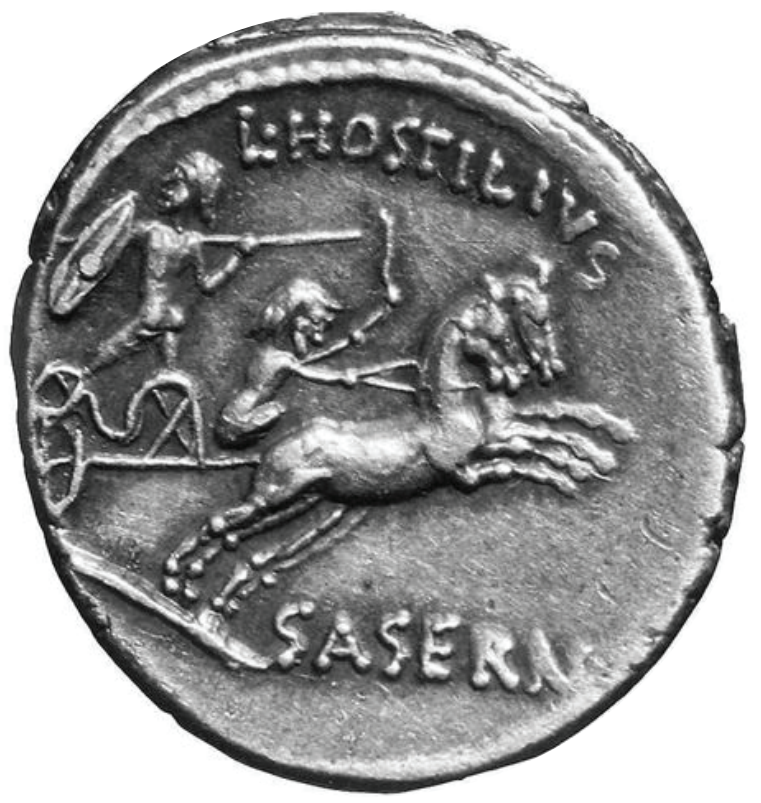

Ryc. 4. Denar rzymski z 48 r. p.n.e., przedstawiający wojowników celtyckich na rydwanie (Źródło: Creative Commons)

(ryc. 3), z terytorium plemienia Skordysków, których uważa się za część tych Celtów, jacy zostali w roku 279 p.n.e. wyparci z terenów Grecji i Macedonii. W samej Grecji, a zwłaszcza w rejonie Termopil, nie odkryto jak dotąd żadnych imponujących znalezisk militarnych tego rodzaju, co ze względu na wtórne wykorzystywanie destruktów przedmiotów wykonanych z żelaza nie wydaje się zaskakujące.

Wyżej opisany zestaw uzbrojenia weryfikuje i uzupełnia poza tym w swojej Geografii Strabon, pisząc, że: „uzbrojenie Celtów jest należycie dostosowane do rozmiarów ich postawnego ciała. Stanowi je: długi miecz, który zwisa u prawego boku, wydłużona, prostokątna tarcza oraz proporcjonalna do tego włócznia"64. Jeżeli chodzi o solidne uzbrojenie ochronne, to było ono przez Celtów rzadko stosowane, choć z pewnością pojawiły się już wtedy pierwsze kolczugii ${ }^{65}$. Korpus wojownika chronił zazwyczaj jedynie skórzany lub tekstylny kaftan i narzucony

${ }^{64}$ Strabo, Geography, vol. 2: Books 3-5, London-New York 1923, 2.4.4.3. Vide: także M. OlĘDZKi, A. Dubicki, op. cit., s. 63.

${ }^{65}$ M. OlęDZKI, A. Dubicki, op. cit., s. 63. 
nań krótki płaszcz. Wojska Celtów składały się z piechoty i jazdy, w której służyła głównie celtycka arystokracja ${ }^{66}$. W dość częstym użyciu pozostawały wówczas także lekkie rydwany (ryc. 4), w tym wypadku z reguły obsługujące wojowników arystokratycznych. O ich roli i działaniach wspomina np. Diodor Sycylijski ${ }^{67}$. Bezdyskusyjnie podstawę armii stanowiła jednak piechota złożona z wolnych wojowników, których status społeczny był nad wyraz wysoki, potwierdzony prawem do noszenia ozdobnej obręczy na szyi (ze srebra lub złota) zwanej torquesem.

Przeciwko tak uzbrojonym i wyposażonym wojownikom stanęli Grecy, politycznie po dawnemu mocno zróżnicowani i skonfliktowani, aczkolwiek wspólny interes, jakim była obrona wolności i niezawisłości Hellady, przywiódł ich chwilowo do zgody i solidarnego działania. Armia, którą łącznie wystawili była niemała, jak podaje Pauzaniasz liczyła bowiem około 25000 wojowników ${ }^{68}$. Wśród nich najbardziej liczący się kontyngent dostarczyli Etolowie, których Związek stanowił w tym czasie największą potęgę w środkowej Grecji. Niemal taki sam był, zdaniem Pauzaniasza, wkład w obronę Beotów, ich wojska miały bowiem posiadać blisko 10000 hoplitów i kilkuset jeźdźców ${ }^{69}$. Nawet z niewielkiej Fokidy przybyło pięciuset jeźdźców i do 3000 pieszych. Stawili się także przedstawiciele Lokrów i Megaryjczyków. Ateńczycy, poza wojownikami różnych formacji, dostarczyli także floty, pilnie odtąd patrolującej wybrzeże Zatoki Malijskiej. Strategiem Ateńczyków był Kallipos, który ze względu na dawną sławę swego miasta objął główne dowództwo, choć było ono raczej honorowe, ponieważ najwięcej do powiedzenia mieli oczywiście Etolowie ${ }^{70}$. Przybyło też pięciuset najemnych żołnierzy z Macedonii ${ }^{71}$ pod wodzą niejakiego Arystodamosa i tyleż samo przysłał na pomoc Antioch z Azji Mniejszej. Generalnie dominowała oczywiście piechota, w tym ciężej uzbrojona - hoplici, ale też nowego typu i lżej uzbrojeni - peltaści. Ci ostatni nie posiadali pancerzy i posługiwali się głównie bronią miotaną. Ciężej uzbrojeni hoplici byli rzecz jasna

66 PAus., 10.19.10-11.

67 Diod. Sic., 4.29.4.

68 PAUs., 10.21.4.

69 Liczba Beotów jest chyba przez Pauzaniasza przesadzona. Trudno sobie wyobrazić, żeby mogli wówczas wystawić tak duży kontyngent, poza tym, jeżeli ją uwzględnimy w całości, to łączna liczba wszystkich jednostek, jakimi dysponowali Grecy byłaby większa od 25000.

70 PAUs., 10.21.5.

71 O tym, że nie byli nimi zapewne sarissoforoi pisali już: M. OlęDzki i A. DubICKi, op. cit., s. 68. 


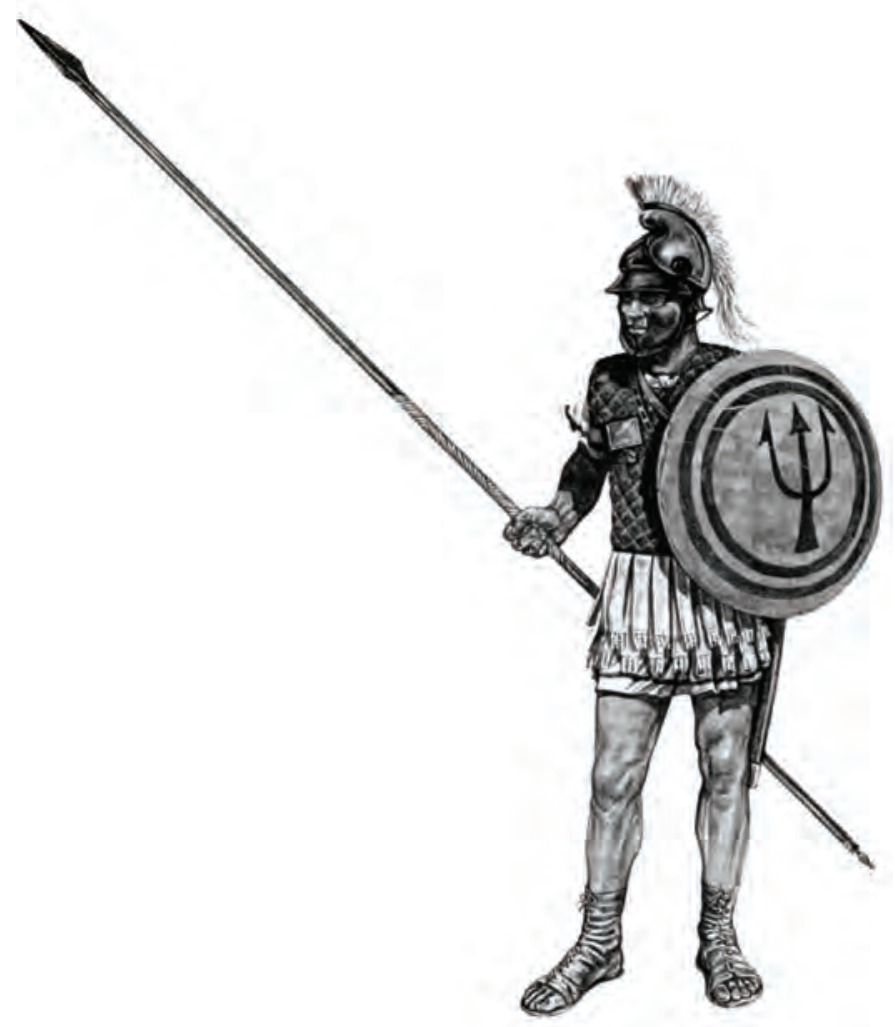

Ryc. 5. „Peltasta” Ifikratesa

(Źró dło: J. WARRY, Armie świata antycznego, Warszawa 1995)

kontynuatorami dawnych tradycji militarnych pod względem taktyki walki, a częściowo też uzbrojenia, aczkolwiek od czasu reformy Ifikratesa ich wygląd i oporządzenie uległy pewnym zmianom. Dokładnych danych na ten temat dostarczają nam dwaj autorzy: Diodor Sycylijski ${ }^{72}$ i Korneliusz Nepos ${ }^{73}$. Zgodnie $\mathrm{z}$ ich słowami Ifikrates wprowadził średnich rozmiarów tarcze, dużo mniejsze i lżejsze od dawnego hoplos okutego szerokim rantem, dłuższe, dochodzące do 3,5-4 m włócznie oraz na szerszą skalę lekkie „pancerze”, wykonane z kilku warstw impregnowanego płótna lnianego (ryc. 5). Nie znaczyło to, że od razu

\footnotetext{
72 Diod. Sic., 15.44.1-4.

${ }^{73}$ Korneliusz Nepos, Żywoty wybitnych mężów (Cornelii Nepotis Vitae, XI. 1), Warszawa 1974 [dalej: NeP., Ifk.], 11.1.
} 
linothorax wyparł całkowicie thorax wykonany z brązu. Piechurzy pierwszych szeregów byli zwykle dalej weń wyposażeni. Natomiast, żeby ich dodatkowo odciążyć, zrezygnowano z metalowych nagolennic, zastępując je częściowo wysokimi, sznurowanymi butami skórzanymi. Poza tym z inicjatywy Ifikratesa wprowadzono nieco dłuższe miecze, o co najmniej $60 \mathrm{~cm}$ długości. Rzecz jasna każdy tak uzbrojony piechur nosił na głowie półotwarty hełm, w omawianym czasie głównie typu trackiego lub tracko-ateńskiego. Należy też dodać, że w przeciwieństwie do Celtów armia grecka dysponowała rozwiniętą quasi "artylerią". Były to zazwyczaj machiny dwóch rodzajów: katapulty strzelające ponadpółmetrowymi bełtami zwane oxybeletes oraz balisty miotające pociski kamienne (lithobolos $)^{74}$. Całości dopełniały różnego typu jednostki wyspecjalizowane, złożone np. z łuczników i procarzy.

\section{Przebieg}

Pozostawiliśmy Celtów nad rzeką Spercheios, której przejście starali się zablokować im Grecy. Jednak najeźdźcom udało się umiejętnie obejść blokadę i przekroczyć rzekę, a właściwie przepłynąć w dolnym jej biegu ${ }^{75}$. Ruszyli następnie szybkim marszem na Herakleję, ale miasta nie udało się im zdobyć. Od około roku miało już ono status członka Związku Etolskiego, a poza tym było silnie ufortyfikowane, Celtowie zaś nie dysponowali żadnymi środkami oblężniczymi. Brennos zarządził więc jego blokadę, a z większością wojsk podszedł pod Termopile. Już następnego dnia doszło do zaciętych walk, po obu stronach prowadzonych wyłącznie przez wojska piesze, bo - jak wspomina Pauzaniasz - wąskie przejście przez Termopile nie dawało możliwości użycia konnicy ${ }^{76}$. Obie strony wykazały się szaleńczą odwagą, ale bardziej skuteczni w boju okazali się Grecy, wsparci dodatkowo przez flotę ateńską, która podpłynęła do wybrzeża Zatoki Malijskiej, tak blisko jak było to tylko możliwe. Z trier ateńskich prowadzony był regularny ostrzał, który Celtom dał się mocno we znaki. Z drugiej strony pozycji greckich, na ich lewej flance, znajdowało się natomiast rozległe bagnisko, o którym pisaliśmy we wstępie, i które także odegrało istotną wówczas rolę. Obejść go nie było można, bo bezpośrednio dochodziło do stromych

\footnotetext{
${ }^{74}$ J. WARRY, op. cit., s. 78-79.

75 Paus., 10.20.7-8.

${ }^{76}$ Paus., 10.21.1-2.
} 
zboczy masywu Kallidromos. Duża część oddziałów celtyckich próbowała je sforsować, co skończyło się dla nich tragicznie ${ }^{77}$. Tego dnia największym męstwem odznaczyli się Ateńczycy, a wśród nich młodzieniec Kydias, który jednakowoż zginął śmiercią bohaterską ${ }^{78}$. Następnie minęło kilka dni na bezowocnych potyczkach, w tym czasie ludzie Brennosa podjęli pierwszą próbę obejścia pozycji greckich ścieżką Anopaia, tą samą, którą w roku 480 przeszli Persowie Kserksesa ${ }^{79}$. Jej trasa miała początek nieopodal ruin miasteczka Trachis, między masywem gór Oita a górami Kallidromos, przez które wiodła najpierw na południe a potem w kierunku północno-wschodnim na tyły wojsk greckich skoncentrowanych w rejonie trzeciej termopilskiej bramy, czyli Bramy Wschodniej. Ścieżką tą udały się wojska celtyckie, ale napotkały silny opór strzegących traktu Fokijczyków pod dowództwem Telezarchosa. Dokonawszy bohaterskich czynów ten ostatni wprawdzie poległ, ale atak wojsk celtyckich wobec determinacji Fokijczyków całkowicie spalił na panewce. Wtedy Brennos wpadł na pomysł dokonania dywersji. Ze swoich wojsk wydzielił specjalny korpus pod dowództwem Kombutisa i Orestoriosa, który z powrotem przeprawił się przez rzekę Spercheios i od północy wtargnął w granice Etolii ${ }^{80}$. Celem było odciągnięcie spod Termopil wojsk etolskich, stanowiących największy kontyngent wśród obrońców. Rozwój wydarzeń miał wkrótce pokazać, że plan był dobry. Wspomniany oddział dotarł do etolskiego miasta Kallion, które zostało zdobyte, a jego mieszkańcy wymordowani. Reakcja Etolów była więc oczywista, wycofali się spod Termopil i ruszyli do ojczyzny celem obrony współplemieńców. Notabene udało im się wkrótce pomścić krzywdy zadane rodakom, zniszczyli bowiem większość wojsk korpusu najezdniczego. Pomagali im w tym Patryjczycy, mieszkańcy sąsiadującego z Etolią miasta Achajskiego ${ }^{81}$. W rejonie

77 Paus., 10. 21.4,7. Według Pauzaniasza liczba tych, co ugrzęźli i utonęli w bagnie była znaczna.

${ }_{78}$ Paus., 10.21.5-6. Po bitwie Grecy z pietyzmem pochowali swoich zabitych, natomiast Celtowie, ku zdziwieniu Pauzaniasza, pozostawili swoich na polu bitwy niepogrzebanych. Na ów passus zwrócił szczególną uwagę L.A. CuRCHIN (The Unburied Dead at Thermopylae, „The Ancient History Bulleitin” 1995, vol. 9, No 2, s. 68-71), który słusznie widzi w nim wpływ szczególnego obyczaju funeralnego. Podzielając ten pogląd pragniemy wyrazić naszą opinię, iż powyższe było zwiastunem stosowanej przez Celtów ekskarnacji, która na dobre objęła większą część świata celtyckiego od okresu środkowolateńskiego po jego schyłek. Vide: B. Cunliffe, op. cit., s. 254.

79 Paus., 10.22.1.

80 Paus., 10.22. 2-3.

${ }^{81}$ PaUs., 10.22. 4-6. 
Termopil sytuacja pozostawała jednak bez zmian. W siódmym dniu od rozpoczęcia działań odmienił ją inny fakt. We wciąż obleganej Heraklei znaleźli się renegaci, którzy obiecali Brennosowi skuteczniej poprowadzić jego wojska ścieżką Anopaia na tyły obrońców Termopil ${ }^{82}$. Tak też się stało. Tym razem broniący traktu Fokijczycy zostali zaskoczeni, sprawiły to niekorzystne dla nich warunki atmosferyczne w postaci gęstej mgły, z której nieoczekiwanie wyłonili się Celtowie. Stawili wprawdzie zacięty opór, ale ostatecznie ulegli. Ich zasługą było natomiast szybkie powiadomienie reszty Greków o zbliżającym się nieprzyjacielu, który był już bliski wzięcia obrońców w kleszcze. Trzeba bowiem dodać, że połowa sił celtyckich z Akichoriosem na czele pozostawała nadal na zajętych wcześniej pozycjach w pobliżu Bramy Zachodniej, szczelnie ją blokując. Informacje pochodzące od Fokijczyków bardzo się przydały. Dzięki nim cała grecka armia miała możliwość wycofania się spod Termopil i translokacji w kierunku wschodnim, w stronę Attyki odpłynęły również ateńskie triery. Zdawało się, że wkrótce śladem Greków podążą Celtowie, którzy tym razem będą górą. To jednak nie miało się wydarzyć. Brennos bowiem, przekonany o tym, że niedługo i tak rozgromi wszystkich Hellenów, ruszył ze swoimi ludźmi bezpośrednio na południe, a jego celem stało się zdobycie Delf i grabież ich nieprzebranych skarbów, które od setek lat były tam deponowane ${ }^{83}$. Powyższe miało się okazać kardynalnym błędem, który ostatecznie zaważył na fiasku całej kampanii.

Tak pokrótce przedstawiała się druga z wybranych przez nas termopilskich batalii, która rzecz jasna nie była końcem zmagań grecko-celtyckich w roku 279. To, co miało się wydarzyć w Delfach, a także po wyparciu z nich wojsk celtyckich nie jest już przedmiotem naszej analizy, niemniej w kilku słowach na koniec ta kwestia zostanie poruszona.

\section{Finat}

Po tym jak Termopile przestały stanowić dla Celtów zaporę w przedostaniu się na tereny południowej Grecji, wojska Brennosa szybkim marszem ruszyły w kierunku Delf. O owych wydarzeniach piszą w szczegółach Justyn ${ }^{84}$

\footnotetext{
${ }^{82}$ Paus., 10.22.9. Pauzaniasz próbuje ich tłumaczyć tym, że pragnęli jak najszybszego odejścia Celtów spod ich miasta.

${ }^{83}$ Paus., 10.22.12.

${ }^{84}$ JUST., Epit., 24.7-8.
} 
i Pauzaniasz ${ }^{85}$. Autorzy ci podają, że kiedy barbarzyńcy znaleźli się w świętym przybytku Apollina, przeciw nim stanęła niewielka armia złożona głównie z Etolów i Fokijczyków (około 4000 wojowników). Ich zdaniem jednak to sam bóg Apollo sprawił, że Celtowie zostali w końcu pokonani i odparci. De facto przyczyniły się do tego złe warunki atmosferyczne spowodowane przedwczesnym nadejściem zimy, połączonym z lokalnym trzęsieniem ziemi. Oczywiście do tego doszło także nadludzkie bohaterstwo obrońców. Wszystko razem mogło rzeczywiście sprawiać wrażenie, że to Niebiosa postarały się ukarać najeźdźców za zbezczeszczenie świętego przybytku. W każdym razie wojska Brennosa zostały odparte i w pośpiechu wycofywały się na północ, gdzie ich resztki połączyły się z pozostawionym przy Termopilach Akichoriosem i jego ludźmi. Ich odwrót z Grecji utrudniła dodatkowo zmiana frontu przez Tessalów, którzy z sojuszników stali się ich wrogami. Wszystko to razem załamało Brennosa, który skutecznie targnął się na swoje życie ${ }^{86}$, a resztki jego armii oraz przybyła z nią ludność celtycka, opuściły Grecję i Macedonię. Hellada była wolna, w Delfach stanął pomnik przedstawiający personifikację Etolii, jako że danina krwi przedstawicieli tej właśnie krainy była największa ${ }^{87}$, a poza tym uchwalono tam nowe panhelleńskie święto - Soteria, co cztery lata obchodzone na cześć zwycięstwa.

\section{Termopile 191 r. p.n.e.}

\section{Przyczyny}

Przede wszystkim stanowiły je knowania Eumenesa króla Pergamonu, który „napuszczał” Republikę na króla Antiocha III Wielkiego po to, żeby odzyskać utracone na jego rzecz terytoria. Z drugiej strony wynikały one z zamierzeń

\footnotetext{
85 PAUS., 10.23.1-10.

${ }^{86}$ Diod. Sic., 12.9.2; Paus., 10.23.12.

87 Wiadomo nawet jak ten pomnik wyglądał, ponieważ zachowały się etolskie monety z połowy wieku III, na których został uwidoczniony: A. Krzyżanowska, Numizmatyka grecka, [w:] Vademecum historyka starożytnej Grecji i Rzymu, t. 1, red. E. WiPszycKA, Warszawa 1982, s. 259, tabl. IX, 8. Wizerunek przedstawia siedzącą na (celtyckich) tarczach kobietę, która prawą ręką wspiera się o włócznię.
} 
samych Rzymian, chcących ukarać krnąbrnego króla, który już kilkukrotnie pokazał, że nie liczy się z nimi w kontekście polityki greckiej. Z trzeciej zaś strony niebagatelną przyczynę stanowiły też namowy Etolów, którzy przy pomocy wielkiego Seleukidy chcieli uzyskać zadośćuczynienie za brak wdzięczności i niewielkie profity, jakie otrzymali od strony rzymskiej za pomoc we wspólnym zwycięstwie nad Filipem V, królem Macedonii. Wszystkie one razem wróżyły, że niebawem wybuchnie wojna ${ }^{88}$. Sam Seleukida się tego spodziewał, skupiony był jednak głównie na sprawach i walkach w Azji Mniejszej.

Pretekstu dostarczyli Etolowie. Pod koniec 192 r. ich wódz Diokles zajął i zaczął fortyfikować Demetriass ${ }^{89}$. Jednocześnie Etolowie pchnęli poselstwo, pod przywództwem przedstawiciela stronnictwa antyrzymskiego Thaosa, do Antiocha z prośbą o pomoc. Król, pomimo że nie był wówczas gotowy na konfrontację z Rzymianami, prowadził bowiem kampanię w Azji, zgodził się ich wspomóc. Etolowie solennie go bowiem zapewniali, że cała Hellada stanie po jego stronie ${ }^{90}$. Zimą 192 r. Antioch przeprawił się do Grecji. Towarzyszyła mu niewielka armia, która według żródeł składała się z zaledwie 10000 piechoty, 500 jeźdźców i 6 słoni $^{91}$. W istocie mogła być silniejsza, licząc około 18000 ludzi ${ }^{92}$. Siły Seleukidy przybiły ostatecznie do etolskiego Pteleon. Jednakże, wbrew zapewnieniom gospodarzy, uzyskał on minimalne jedynie wsparcie. Największym niepowodzeniem było zwłaszcza to, że nie pozyskał wsparcia Macedonii, osłabionej wprawdzie po ostatniej wojnie z Rzymem (lata 200-197), ale będącej w istocie jedyną liczącą się siłą militarną w Grecji. Wkrótce potem Seleukida zajął Chalkis, a następnie udał się do tessalskiej Lamii, aby uzyskać

88 Szerzej o okresie obejmującym lata 198-192, określanym przez niektórych badaczy jako czas „zimnej wojny” (w tym o stosunkach dyplomatycznych obu stron konfliktu i ich sojuszników): App., Syr., 5-3.14, 23-25, 34-36; Liv., 35.12-13, 15-18, 20, 23-24, 32-33; PolyB., 18.47-48; 50-52; E. Badian, Rome and Antiochus the Great: A Study in Cold War, „Classical Philology” 1959, vol. 54, No 2, s. 81-95; K. KĘCIEK, Wojna syryjska, Warszawa 2017, s. 95-124; T. WA£EK, Dzieje upadku monarchji macedońskiej, Kraków 1924, s. 156-163.

89 Liv., 35.34.

90 App., Syr., 46-47.

91 App., Syr., 48; Liv., 35.43. Podane przez nich liczby zostały przyjęte przez niektórych badaczy, vide: B. BRAvo, E. WipszyCKA, Historia starożytnych Greków, t. 3, Warszawa 1992, s. 117; T. WA£EK, op. cit., s. 164 .

92 Za taką liczebnością sił Seleukidy opowiedzieli się m.in.: B. BAR-Kochva, The Seleucid Army: Organization and Tactics in the Great Campaigns, Cambridge 1976, s. 18, 158; K. KĘCIEK, op. cit., s. 130. 
pomoc tamtejszych polis ${ }^{93}$. W tym czasie senat wyznaczył na konsula do działań w Grecji homo novus - Maniusza Acyliusza Glabriona, który wraz z siłami otrzymanymi od senatu oraz oddziałami rzymskimi stacjonującymi w Grecji i oczywiście sprzymierzeńcami, poprowadził przeciwko Antiochowi 20000 piechoty, 2000 jazdy oraz 15 słoni $^{94}$. Te ostatnie Republika otrzymała od władcy Numidów - Masynissy. Po wylądowaniu w Grecji siły rzymskie pomaszerowały przez Epir do Tessalii. Tam stanęły w Larissie, skąd pomaszerowały następnie do Zatoki Malijskiej. Sam Antioch natomiast opuścił Lamię i przez dolinę Tempe udał się na południe. Tracił co prawda Tesalię, ale mógł dzięki temu skupić się na obronie środkowej Grecji. Tam właśnie, ze względu na to, iż dysponował mniejszymi niż Rzymianie siłami, postanowił stawić im czoło w Termopilach.

\section{Przeciwnicy}

Trzon armii Antiocha stanowiły kontyngenty osadników wojskowych, pochodzenia greckiego i macedońskiego, którzy dysponowali przydzielonymi im działkami ziemi z obowiązkiem służenia w falandze ${ }^{95}$. Sarissophoroi (nosiciele sariss) byli uzbrojeni m.in. w hełmy typu trackiego, krótki miecz typu machaira, lniany pancerz (linothorax) i przede wszystkim w długą 5-7 m włócznię, sarisę ${ }^{96}$. Ponadto w skład armii Seleukidów wchodziła formacja Srebrnych Tarcz (argyraspides), która walczyła przede wszystkim jako „piechota liniowa” - hypsaspiści, ochraniająca szeregi falangi, po zmianie zaś uzbrojenia mogła również walczyć w falandze ${ }^{97}$. Gwardię reprezentowały dwie konne chiliarchie - agema i hetajrowie ${ }^{98}$. Rdzeń grecko-macedońskich wojsk wzmacniali osadnicy wojskowi wywodzący się z ludów bałkańskich, a także kontyngenty dostarczane przez ludy podległe Seleukidom 99 . Była to przede wszystkim lekkozbrojna jazda (w tym konni łucznicy), a także piesi łucznicy, oszczepnicy i procarze. Ponadto

${ }_{93}$ O działaniach politycznych i militarnych oraz sytuacji Antiocha na początku jego pobytu w Grecji: Apr., Syr., 12.49-14.59, 16.66-70; Liv., 35.43-48, 50-51, 36.5-13; K. Kє̨CIEK, op. cit., s. 130-152.

94 App., Syr., 71; Liv., 36.14.

95 O falangitach i osadnictwie wojskowym w państwie Seleukidów: B. BAR-Kochva, op. cit., s. 20-48; B. Bravo, E. WipszycKa, op. cit., s. 55; K. KęCiEK, op. cit., s. 47-51.

96 B. Bravo, E. WipsZyckA, op. cit., s. 55; K. KęCIEK, op. cit., s. 49.

${ }^{97}$ B. Bar-Kochva, op. cit., s. 56-66; B. BRavo, E. Wipszycka, op. cit., s. 55-56; K. KęCIEK, op. cit., s. 51-52.

98 B. BAR-Kochva, op.cit., s. 67-75; K. KęCIEK, op. cit., s. 52-53.

99 B. BAR-Kochva, op. cit., s. 48-53, 75-84. 
skład wojsk Seleukidów uzupełniały rydwany i słonie bojowe, a także najemnicy (wśród nich m.in. celtyccy Galatowie z centrum Anatolii) ${ }^{100}$. Taktyka armii Seleukidów, podobnie jak pozostałych państw hellenistycznych, opierała się na taktyce połączonych broni. Trzon stanowiła falanga, która liczyła od 8 do 32 szeregów. Pierwszych pięć trzymało włócznie poziomo, pozostałe szeregi trzymały je uniesione i lekko pochylone, aby zatrzymywać pociski nieprzyjaciela. Skrzydła osłaniały formacje gwardii oraz konnica.

Armia rzymska składała się również przede wszystkim z obywateli, którzy ze względu na poziom zasobności finansowej walczyli w dostosowanych do niego formacjach: najbiedniejsi jako lekkozbrojni welici (velites), średniozamożni w piechocie, gdzie tworzyli trzy grupy różniące się wiekiem i uzbrojeniem (hastati, principes i triarii), najbogatsi natomiast służyli w jeździe. Siły te walczyły w formacji triplex acies, poszczególne oddziały z kolei w manipułach, które ustawiane były na kształt szachownicy. Przerwy między oddziałami pierwszego szeregu (hastati) wypełniali principes, którzy obrzucali przeciwnika pilii (nie dającymi się wyciągnąć z tarczy przeciwnika oszczepami), a następnie dokonywali uderzenia. W razie niepowodzenia do akcji wchodzili triarii, zamiast oszczepów wyposażeni we włócznie ${ }^{101}$. Reasumując, piechota rzymska posiadała owalne tarcze, oszczepy typu pilum, włócznię (tylko triarii), miecze typu gladius, sztylety (pugio) oraz hełmy - wówczas typu Montefortino ${ }^{102}$. Ponadto oddziały rzymskie wspierali sprzymierzeńcy (socii) uzbrojeni i walczący na sposób rzymski, a także ludy tradycyjnie związane sojuszem z Rzymem ${ }^{103}$.

\section{Przebieg}

Armia Antiocha, która wyruszyła do Termopil liczyła, jak powiedzieliśmy, 10000 piechoty, 500 jazdy i 6 słoni $^{104}$. Seleukida zdecydował się stawić opór stronie rzymskiej nie tak, jak dotychczas to czyniono, tj. w Bramie Środkowej (ryc. 2), gdzie znajdowały się resztki wcześniejszych umocnień, ale w tzw.

${ }^{100}$ G.T. Griffith, The Mercenaries of the Hellenistic World, Cambridge 1935, s. 142-170; K. KĘCIEK, op. cit., s. 53-54.

101 Taktyka legionów rzymskich: P. Connolly, op. cit., s. 140-142; N. SEKunda, The Republican Roman Army, 200-104 B.C., London 1996, s. 18-21.

102 O uzbrojeniu wojsk Republiki: P. Connolly, op.cit., s. 130-133; N. Sekunda, The Republican Roman Army..., s. 4-10.

${ }_{103}$ P. Connolly, op. cit., 133-134; N. Sekunda, The Republican Roman Army..., s. 38-39.

104 App., Syr., 75. 
Bramie Wschodniej ${ }^{105}$. Było to spowodowane nie tylko ciasnym przejściem, ale również tym, że od zachodu zamiast linii stromych skał znajdowały się stosunkowo łagodne górskie zbocza, które umożliwiały umieszczenie na nich machin miotających. Wymieniony fragment terenu umocniono więc kamiennym murem, który wspinał się stopniowo po stoku wzgórza ku południowi, kończąc się na pionowym klifie. Na nim to umieszczono machiny miotające, a u jego podnóża postawiono lekkozbrojnych. Umocnienie to miało osłaniać główne siły królewskie przed obejściem ich linii. Poza tym ten fragment terenu dodatkowo ochraniały od północy parowy i jary. Sama Brama Wschodnia została natomiast umocniona podwójnym wałem ziemnym (pierwszy był niższy od drugiego) oraz rowem, który od wschodu, tj. od strony morza, był poza tym ochraniany przez bagna ${ }^{106}$. Na niższym wale ustawiła się falanga, na wyższym oddziały miotające. Przed rowem natomiast lekkozbrojni i Srebrne Tarcze. Na prawym skrzydle, już blisko morza, stanął Antioch głównie w otoczeniu jazdy i bojowych słoni. Blisko wybrzeża dryfowała jego flota zabezpieczająca całość operacji. Dla ochrony ścieżki Efialtesa i wąwozu Asopos wyznaczono tradycyjnie Etolów w liczbie 2000 ludzi, którzy wcześniej obsadzili Hypatę, a teraz usadowili się na trzech wierzchołkach pasma Kallidromos - Kallidromon, Roduntia i Tychiunt ${ }^{107}$, gdzie wznieśli prowizoryczne umocnienia ${ }^{108}$.

Kiedy Glabrion przybył do Termopil, założył obóz w Bramie Środkowej. Następnie zdecydował, że główne rzymskie siły będą atakowały umocnienia Antiocha, podczas gdy dwa oddziały, pod dowództwem Marka Porcjusza Katona i Lucjusza Waleriusza Flakkusa, prowadzone przez jeńców etolskich, obejdą stanowiska królewskie ścieżką Efialtesa ${ }^{109}$. Następnego dnia Rzymianie zaatakowali pozycje seleukidzkie. Pierwszy atak zakończył się niepowodzeniem i odparciem wojsk rzymskich. Drugi doprowadził do tego, że lekkozbrojni wspierani przez Srebrne Tarcze wycofali się za mur. Również kolejne ataki zostały powstrzymane przez długie włócznie falangitów i częściowo przez poprzeczny rów ${ }^{110}$. W pewnym momencie żołnierze królewscy spostrzegli uciekających

105 K. KęCIEK, op. cit., s. 157.

106 Opis umocnień Antiocha: App., Syr., 78; Liv., 36.16; B. BAR-KocHVA, op. cit., s. 160-161;

K. KĘCIEK, op. cit., s. 157-158.

107 App., Syr., 78-79.

108 Tak sądzi np.: K. KĘCIEK, op. cit., s. 159 oraz przyp. 1 na tej stronie.

109 App., Syr., 80; Liv., 36.17 (każdy z nich prowadził 2000 ludzi).

110 App., Syr., 84; Liv., 36.18. 
Etolów z Kallidromonu, którzy zostali pobici w nocy przez oddział Katona. Ten w przeciwieństwie do Flakkusa, który cofnął się po pierwszym niepowodzeniu w walce z Etolami na szczytach Roduntii i Tychiuntu, zawrócił do Bramy Zachodniej skąd wspiął się na stoki dzisiejszej Starej Damasy. Stamtąd poszedł na południe po dotarciu do ścieżki Efialtesa. W związku z powyższym obrona królewska została zaskoczona i całkiem się załamała. Atakowani nie tylko zaniechali dalszej obrony, ale gremialnie czmychnęli do obozu mając na względzie jedynie ochronę własną i własnych dóbr. Tymczasem główne siły konsula oraz oddział Katona wdarły się tam za nimi pustosząc obóz. Sam Antioch salwował się wówczas ucieczką. Bezładny tłum uciekinierów ścigano aż do Skarphei, leżącej około $10 \mathrm{~km}$ na północ od Termopil. Z armii królewskiej ocalała tylko jazda i garść piechoty, której większość oraz wszystkie słonie zostały zabite w trakcie masakrowania uciekinierów ${ }^{111}$. W tym czasie 2000 Etolów z Heraklei Trachińskiej zdobyło obóz rzymski, ale wkrótce zostali oni odrzuceni przez wojska konsula, które następnie udały się do obozu Antiocha kontynuując tam dzieło rabunku. Zwycięzcy stracili w tych starciach jedynie 200 zabitych $^{112}$.

\section{Po bitwie}

Po bitwie Acyliusz pomaszerował do Fokidy i Beocji. Natomiast Antioch udał się do Chalkis, skąd odpłynął w asyście resztek swoich wojsk w kierunku Azji. Nierówną walkę prowadzili już tylko osamotnieni Etolowie. Konflikt rzymsko-seleukidzki rozstrzygnąć się miał w Azji Mniejszej, w roku 190, kiedy to Antioch III zwany Wielkim poniósł sromotną klęskę na polach Magnezji.

111 Appian i LiwiUsz szacowali straty armii królewskiej na 10000 ludzi: App., Syr., 90 (wraz z jeńcami); LrV., 36.19 (prócz garstki ocalonych).

112 App., Syr., 90; Liv., 36.19. 


\section{BIBLIOGRAFIA}

\section{Źródła drukowane}

Flawiusz Arrian, Wyprawa Aleksandra Wielkiego, Wrocław 2004.

Appian z Aleksandrii, Historia Rzymska, t. 1-2, Wrocław 1957.

Diodorus of Sicily, The Library of the History, vol. 2: Books 2.35-4.58, London-Cambridge 1967.

Diodorus of Sicily, The Library of the History, vol. 4: Books IX-12.40, trans. C.H. Oldfather, London-Cambridge 1956.

Diodorus of Sicily, The Library of the History, vol. 6: Books 14-15.19, London-Cambridge 1954.

Diodorus of Sicily, The Library of the History, vol. 11: Fragments of books XXI-XXXII, trans. F.R. Walton, Cambridge-London 1957.

Herodot, Dzieje, Warszawa 1954.

Herodotus, Histories, vol. 3: Books VIII-IX, London-Cambridge 1938.

Marek Junianus Justyn, Zarys dziejów powszechnych starożytności na podstawie Pompejusza Trogusa, Warszawa 1988.

Tytus Liwiusz, Dzieje Rzymu od zatożenia miasta. Księgi XXXV-XL, Wrocław 1981.

Korneliusz Nepos, Żywoty wybitnych mężów (Cornelii Nepotis Vitae, XI. 1), Warszawa 1974.

Pausanias, Description of the Greece, vol. 4: Books VIII-X, London-Cambridge 1935.

Pauzaniasz, Wędrówka po Helladzie. Ustóp boga Apollona, Wrocław 1989.

Polibiusz, Dzieje, t. 2, Wrocław 2005.

Plutarch, Moralia, vol. 3: 172 A - 263 C, Cambridge-London 1961.

Plutarch, Powiedzenia wodzów i królów. Powiedzenia spartańskie, Warszawa 2006.

Plutarch z Cheronei, Żywoty stawnych mężów, Wrocław-Warszawa-Kraków-Gdańsk 1976.

Strabo, Geography, vol. 2: Books 3-5, London-New York 1923.

\section{Opracowania}

Badian E., Rome and Antiochus the Great: A Study in Cold War, „Classical Philology” 1959, vol. 54, No 2, s. 81-99.

Bar-Kochva B., The Seleucid Army: Organization and Tactics in the Great Campaigns, Cambridge 1976.

Bravo B., Wipszycka E., Historia starożytnych Greków, t. 3, Warszawa 1992. 
Connolly P., Greece and Rome at War, London 2006.

Cunliffe B., Starożytni Celtowie, Warszawa 2003.

Curchin L.A., The Unburied Dead at Thermopylae, „The Ancient History Bulletin” 1995, vol. 9, No 2, s. 68-71.

Dubicki A., Olędzki M., Cosstoboci - less known participants of the Marcomannic wars, „Ephemeris Napocensis” 2018, vol. 28, s. 155-166.

Fields N., Termopile 480 p.n.e. Ostatnia walka Trzystu, Kraków 2008.

Griffith G.T., The Mercenaries of the Hellenistic World, Cambridge 1935.

Hammond N.G.L., Dzieje Grecji, Warszawa 1994.

Kęciek K., Wojna syryjska, Warszawa 2017.

Krzyżanowska A., Numizmatyka grecka, [w:] Vademecum historyka starożytnej Grecji i Rzymu, t. 1, red. E. Wipszycka, Warszawa 1982, s. 253-304.

Kulesza R., Maraton, wyd. 2, Warszawa 2005.

Kulesza R., Sparta w V-IV wiekup.n.e., Warszawa 2003.

Kulikowski M., Wojny Rzymu z Gotami. Od III wieku do Alaryka, Oświęcim 2015.

Lach G., Salamina-Plateje 480-479 p.n.e., Warszawa 2010.

Łoposzko T., Starożytne bitwy morskie, Gdańsk 1994.

Olędzki M., Z problematyki latynizacji i celtyzacji na obszarze Kotliny Karpackiej, [w:] Archeologia et Historia. Ksiega jubileuszowa dedykowana Pani Profesor Romanie Barnycz- Gupieńcowej, red. L. Kajzer, Łódź 2000, s. 323-329.

Olędzki M., Dubicki A., Celtowie w natarciu. Termopile i Delfy w 279 roku przed Chr., [w:] Celtica. Studia z dziejów Celtów, t. 5, red. D. Waszak, Kalisz-Warszawa 2018, s. 58-78.

Ray jr F.E., Land Battles in $5^{\text {th }}$ Greece: A History and Analysis of 173 Engagements, Jefferson-London 2009.

Schaff U., Keltische Helme, [w:] Antike Helme. Sammlung Lipperheide und andere Bestände des Antikenmuseums Berlin, Mainz 1988, s. 293-317.

Sekunda N., The Greek Hoplite, 480-323 B.C., Oxford 2000.

Sekunda N., The Persian Army, 560-330 B.C., London 1992.

Sekunda N., The Republican Roman Army, 200-104 B.C., London 1996.

Składanek B., Historia Persji, t. I: Od czasów najdawniejszych do najazdu Arabów, Warszawa 1999.

Szubelak B., Hoplita grecki VII-V w.p.n.e. Studium bronioznawcze, Zabrze 2007.

Vouvalidis K. et al., Palaeogeographical reconstruction of the battle terrain in Ancient Thermopylae, Greece, „Geodinamica Acta” 2010, vol. 23, No 5-6, s. 241-253.

Wałek T., Dzieje upadku monarchji macedońskiej, Kraków 1924.

Warry J., Armie świata antycznego, Warszawa 1995. 
Woźniak M.A., Armie starożytnej Persji. Od powstania państwa Achemenidów do upadku imperium sasanidzkiego, Zabrze 2010.

Zakrzewski K., Uschytku świata antycznego, Warszawa 1964.

\section{Marek Olędzki, Damian Waszak \\ THERMOPYLAE THREEFOLD}

Summary. Thermopylae, situated in Greece, was a special place created by Nature, which played an important and incomparable role in the times of the history of the antique wars. The place formed a specific 'eye of the needle' which impeded all types of invaders to get into the Middle and Southern Greece, that is to the most politically and economically important centres. It was determined by its land formation of a narrow passage between the steep Kallidromos mountains and the seaside or, more accurately the Malian Gulf. The geomorphological studies of Greek scientists made this situation even more precise by proving that next to the steep mountains there was an extensive swamp, made by warm sulphur springs beating above. It was this swamp, therefore, that made the passage through Thermopylae even narrower, approximately about several dozen metres wide (Fig. 2). This place is the result of the reconstruction as the current situation (Fig. 1) does not resemble of the landform of the antique times. The fundamental change was caused by the accumulative activity of the nearby Spercheios river 'pushing aside' the bank of the Gulf by a few metres as well as by the change of the previous swamp into the travertine rock present today.

The authors of the paper analyse three big military conflicts in Thermopylae, which took place in the three memorable years that is: 480,279 and $191 \mathrm{BC}$. The selection criterion was the epoch when they happened, that is the antique, as well as the active background of the nature of the location, which remained unchanged in the discussed times. In addition, all three described conflicts, strictly connected with the geomorphological determinants of Thermopylae, found their course with far-reaching similarities. The first part discusses the Xerxes' army invasion of Greece in 480 BC and the heroism of the 300 led by Leonidas. As is widely known, this battle has already been properly recognized in the literature on the subject. The original contribution of the authors is taking into consideration the newly discovered geomorphological determinants of Thermopylae, mentioned above. This applies to a significant degree the other two conflicts discussed in the article, newly interpreted by the authors, that is the invasion of Brennus with the Celtic hordes intending to settle in the Hellas (279 BC) and unfortunate battles of Antiochus III with the Romans in 191 BC.

Keywords: Thermopylae, geomorphical investigations, marsh, Xerxes, Persians, Brennos, Celts, Aetolians, Romans, Callidromos Mountains, Antiochus III 